\title{
CRUSTAL DEFORMATION ANALYSIS OF THESSALY (CENTRAL GREECE) BEFORE THE MARCH 2021 EARTHQUAKE SEQUENCE NEAR ELASSONA-TYRNAVOS (NORTHERN THESSALY)
}

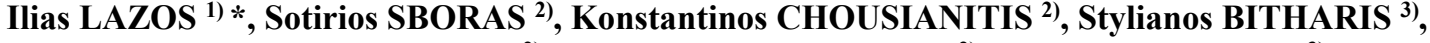 \\ Evaggelos MOUZAKIOTIS ${ }^{2)}$, Vassilios KARASTATHIS ${ }^{2)}$, Christos PIKRIDAS ${ }^{3)}$, \\ Aristeidis FOTIOU ${ }^{3)}$ and Dimitris GALANAKIS ${ }^{4)}$ \\ 1) Aristotle University of Thessaloniki, School of Geology, University Campus, Greece \\ ${ }^{2)}$ Institute of Geodynamics, National Observatory of Athens, Lofos Nymfon, Athens \\ 3) Aristotle University of Thessaloniki, School of Rural and Surveying Engineering, University Campus, Thessaloniki, Greece \\ 4) Hellenic Survey of Geology \& Mineral Exploration (HSGME), Acharnes, Athens \\ *Corresponding author's e-mail: iliaslazoseng@yahoo.com
}

\section{ARTICLE INFO}

Article history

Received 3 May 2021

Accepted 16 June 2021

Available online 13 July 2021

\section{Keywords:}

Active tectonics

Crustal deformation

GPS data

2021 Elassona-Tyrnavos earthquake

Greece

\section{ABSTRACT}

Thessaly lies on the Aegean (micro-)plate, undergoing internal crustal deformation due to the plate relative motion against the adjacent Anatolian and Nubian plates. As a result, the whole Thessalian Basin was supposed to be under an extensional tectonic regime of N-S direction. However, the recent earthquake sequence of March 2021 which occurred close to the northwestern margin of the basin revealed NE-SW direction of extension. Based on 7-year GPS measurements recorded by stations installed within and around the basin we assessed four deformational parameters for Thessaly aiming at the understanding of the deformation processes that control the region. These parameters are i) the Maximum Horizontal Extension (MAHE), ii) the Total Velocity (TV), iii) the Maximum Shear Strain (MSS), and iv) the Area Strain (AS). The results show that during the monitoring period, Thessaly moved toward the S-SW with a simultaneous clockwise rotation and underwent dispersed deformation mostly associated with dilatation. Focusing on the epicentral area of the 2021 sequence, strain during the 7-year period was rather low in all three strain parameters, implying a mature stage of elastic strain accumulation before the fault rupture.

\section{INTRODUCTION}

Located in the back-arc area of the Hellenic Arc, the Aegean (micro-)plate in the region of Thessaly is considered to undergo a roughly N-S stretching, as geological, seismological and geodetic data suggested so far. According to Caputo and Pavlides (1991, 1993), who carried out meso-structural analyses of the faults recognized in the area, Thessaly is characterised by three tectonic phases since Neogene: i) a ca. E-W orientated compression during early to middle Miocene, ii) a NE-SW orientated extension during Pliocene - Early Pleistocene, and iii) a $c a$. N-S orientated extension since middle Pleistocene. It was also suggested that the current extensional regime is documented on all the E-W-striking normal faults that dominate the area. This regime is also supported by seismological data (i.e. focal mechanisms; Fig. 1), although most of them refer to the southern part of Thessaly, while at the same time the seismological observations are limited at the northern part. Indeed, either from significant recent earthquakes, such as the 1980 Volos (SE Thessaly) sequence (GCMT catalogue; EMMA catalogue; Papazachos et al., 1983; Ekstrom and England, 1989; Taymaz et al., 1991; Kiratzi and Louvari, 2003; Papadimitriou and
Karakostas, 2003; Kourouklas et al., 2021), microseismic investigations (Hatzfeld et al., 1989), or diachronic minor seismicity (e.g. RCMT catalogue; GCMT catalogue), the prevailing focal mechanisms suggest E-W-striking normal faulting associated with $\mathrm{N}-\mathrm{S}$-directed extensional stress field. Regarding the GPS-derived strain estimation from previous works (Kahle et al., 2000; Jenny et al., 2004; Hollenstein et al., 2008; Perouse et al., 2012; Müller et al., 2013; Chousianitis et al., 2015), the strain rate range (especially the one developed along the major ellipse axe) is sometimes contradictory, as either extremely low to high values and/or different, rapidly changing dilatation orientations, related to the corresponding extension rate ones, are documented (due to sparsely located interpolated data as well).

On March 3, 2021 a strong $\left(\mathrm{M}_{\mathrm{w}} 6.3\right)$ earthquake occurred west of Tyrnavos town (Northern Thessaly; Table 1; Fig. 1b) and was followed, one day later, by a second strong $\left(\mathrm{M}_{\mathrm{w}} 6.0\right)$ event (Table 2), implying rupture on two adjacent fault segments. The 12 proposed moment tensor solutions for the first event (EMSC-CSEM website) are quite similar, revealing NW-SE-striking (pure) normal faulting, and hence NE-SW orientated $T$-axis. The 4 proposed moment 


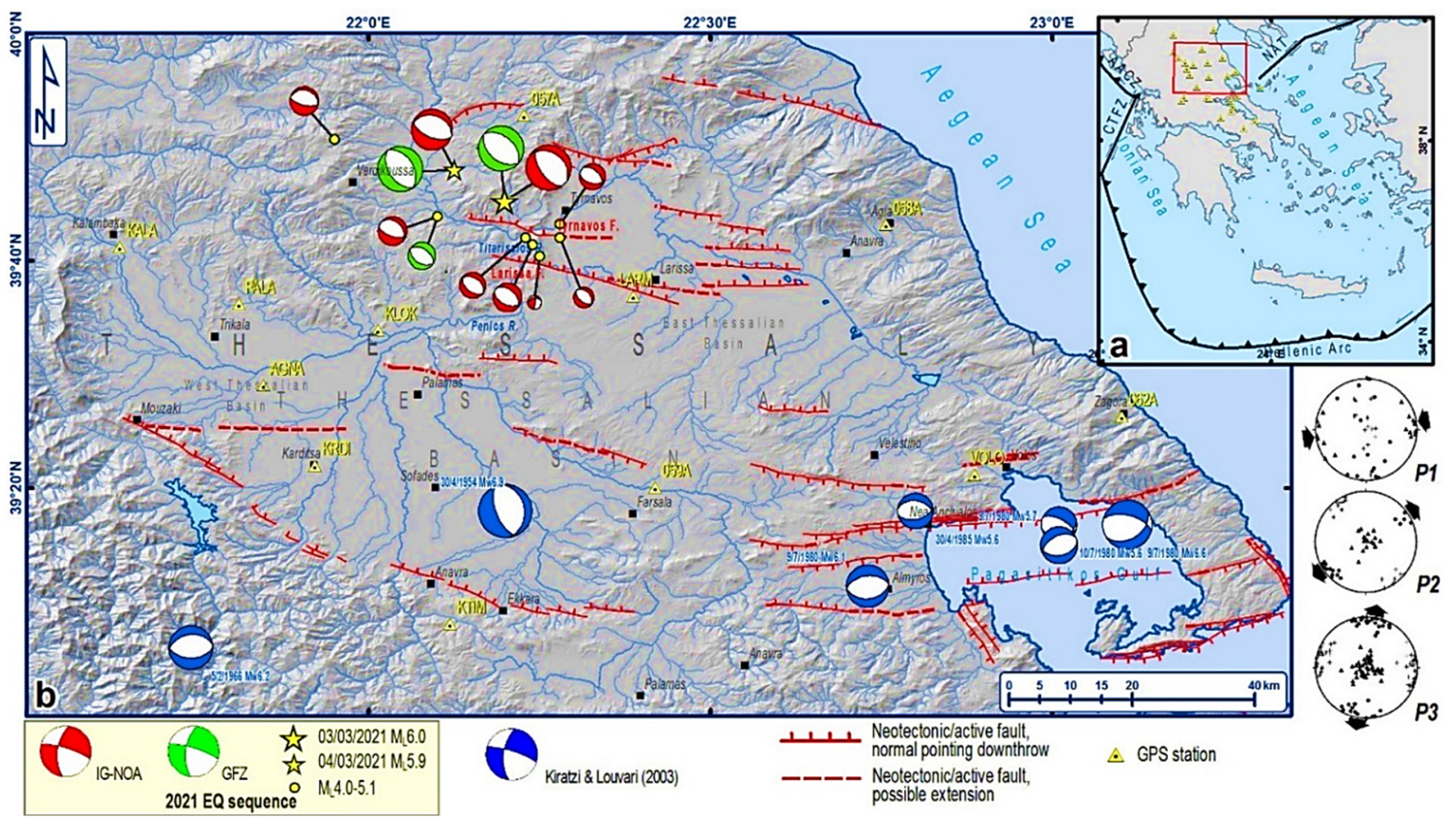

Fig. 1 (a) Map of the Aegean region showing the major crustal-scale tectonic structures (AACZ = ApulianAegean Collision Zone; CTFZ = Cephalonia Transform Fault Zone; NAT $=$ North Aegean Trough) the location of the GPS stations used in this study and the location of (b). (b) Hillshade map of Thessaly showing the major neotectonic/active faults (after Galanakis, 1990; Caputo and Pavlides, 1991; 1993; Perissoratis et al., 1991; Sboras, 2011; Caputo et al., 2012; GreDaSS), the GPS stations from (a) included in this area, focal mechanisms of past significant events (Kiratzi and Louvari, 2003) and the focal mechanisms proposed by IG-NOA and GFZ for the strongest shocks of the 2021 earthquake sequence near Tyrnavos. P1, P2 and P3 (bottom right corner) are the three last tectonic phases after a meso-structural analysis in Thessaly (Caputo and Pavlides, 1993) revealing ca. E-W compression during early to middle Miocene (P1), NE-SW extension during Pliocene - Early Pleistocene (P2), and ca. N-S extension since middle Pleistocene to Today (P3).

Table 1 Moment tensor solution for the March 03, 2021 seismic event (EMSC-CSEM website).

\begin{tabular}{|c|c|c|c|c|c|c|c|c|c|c|}
\hline \multirow[t]{2}{*}{ Lat $\left(^{\circ}\right)$} & \multirow[t]{2}{*}{ Long $\left({ }^{\circ}\right)$} & \multirow{2}{*}{$\begin{array}{c}\text { Depth } \\
(\mathrm{km})\end{array}$} & \multirow[t]{2}{*}{$\mathrm{M}_{\mathrm{w}}$} & \multicolumn{3}{|c|}{ Nodal plane 1} & \multicolumn{3}{|c|}{ Nodal plane 2} & \multirow[t]{2}{*}{ Agency } \\
\hline & & & & Strike $\left({ }^{\circ}\right)$ & $\operatorname{Dip}\left({ }^{\circ}\right)$ & Rake $\left({ }^{\circ}\right)$ & Strike $\left({ }^{\circ}\right)$ & $\operatorname{Dip}\left({ }^{\circ}\right)$ & Rake $\left(^{\circ}\right)$ & \\
\hline 39.6 & 21.9 & 12 & 6.3 & 307 & 36 & -100 & 139 & 55 & -83 & USGS \\
\hline 39.7 & 22.1 & 12 & 6.3 & 119 & 45 & -109 & 324 & 48 & -72 & GCMT \\
\hline 39.8 & 22.2 & 12 & 6.3 & 321 & 36 & -77 & 125 & 55 & -100 & СРPТ \\
\hline 39.8 & 22.1 & 10 & 6.3 & 130 & 45 & -90 & 310 & 44 & -89 & GFZ \\
\hline 39.8 & 22.3 & 7 & 6.2 & 147 & 48 & -94 & 332 & 43 & -85 & ERD \\
\hline 39.8 & 22.2 & 19 & 6.3 & 309 & 36 & -91 & 0 & 0 & 0 & UOA \\
\hline 39.8 & 22.2 & 10 & 6.2 & 321 & 33 & -78 & 127 & 57 & -98 & IPGP \\
\hline 39.7 & 22.2 & 10 & 6.3 & 126 & 37 & -103 & 323 & 53 & -79 & KOERI \\
\hline 39.8 & 22.2 & 7 & 6.2 & 135 & 45 & -90 & 315 & 45 & -90 & OCA \\
\hline 39.7 & 22.2 & 6 & 6.2 & 131 & 54 & -92 & 314 & 36 & -88 & AUTH \\
\hline 39.8 & 22.2 & 4 & 6.3 & 305 & 33 & -108 & 146 & 59 & -79 & NOA \\
\hline 39.6 & 22.1 & 10 & 6.3 & 116 & 41 & -114 & 327 & 53 & -70 & INGV \\
\hline
\end{tabular}

tensor solutions for the second event (EMSC-CSEM website) suggest (pure) normal faulting, but with a difference to the strike of the nodal planes: GFZ and UoA report NW-SE strike, whereas NOA and AUTh WNW-ESE strike, corresponding to NE-SW- and NNE-SSW-directed $T$-axes, respectively. Moment tensors of the $M_{w} \geq 5.0$ events of the sequence persist on indicating NW-SE-striking normal faulting. The most possible and mapped candidate neotectonic faults in the broader epicentral area are the Tyrnavos and Larissa faults (Fig. 1b; Caputo, 1993; Caputo and Pavlides, 1993; GreDaSS). However, the epicentral locations of the two strongest shocks, the aftershock spatial distribution, and the proposed focal mechanisms imply the presence of an unmapped active fault zone. The epicentral area lacks significant 
Table 2 Moment tensor solution for the March 04, 2021 seismic event (EMSC-CSEM website).

\begin{tabular}{|c|c|c|c|c|c|c|c|c|c|c|}
\hline \multirow[t]{2}{*}{ Lat $\left(^{\circ}\right)$} & \multirow[t]{2}{*}{ Long $\left(^{\circ}\right)$} & \multirow[t]{2}{*}{ Depth (km) } & \multirow[t]{2}{*}{$\mathrm{M}_{\mathrm{w}}$} & \multicolumn{3}{|c|}{ Nodal plane 1} & \multicolumn{3}{|c|}{ Nodal plane 2} & \multirow[t]{2}{*}{ Agency } \\
\hline & & & & Strike $\left({ }^{\circ}\right)$ & $\operatorname{Dip}\left({ }^{\circ}\right)$ & Rake $\left({ }^{\circ}\right)$ & Strike $\left({ }^{\circ}\right)$ & $\operatorname{Dip}\left({ }^{\circ}\right)$ & Rake $\left(^{\circ}\right)$ & \\
\hline 39.8 & 22.1 & 15 & 6.1 & 308 & 50 & -92 & 0 & 0 & 0 & UOA \\
\hline 39.8 & 22.1 & 7 & 5.9 & 109 & 60 & -89 & 287 & 30 & -92 & AUTH \\
\hline 39.8 & 22.1 & 8 & 6.0 & 287 & 31 & -95 & 112 & 59 & -87 & NOA \\
\hline 39.8 & 22.2 & 17 & 6.3 & 146 & 48 & -91 & 329 & 41 & -88 & GFZ \\
\hline
\end{tabular}

instrumentally recorded earthquakes (IG-NOA); in the broader epicentral area, historic earthquake catalogues (e.g. Papazachos and Papazachou, 2003) refer to strong events $(M \geq 6.0)$, but they are too old $\left(18^{\text {th }} \mathrm{c}\right.$. and older) to be accurately located and hence associated with a particular fault.

The scope of this work was to investigate the crustal strain of Thessaly during a 7-year period and to investigate the question that arose after the 2021 Tyrnavos seismic sequence: is the geologically estimated N-S oriented active extension of Thessaly compatible with the regional crustal deformation and consequently with the 2021 Tyrnavos earthquakes?

\section{CRUSTAL DEFORMATION}

A geodetic analysis was performed, based on the implementation of the kinematic information provided by the GPS data processing (Bitharis, 2015; Bitharis et al., 2016). In particular, the geodetic velocities are recorded by a dense network of 27 permanent GPS stations, while they are applied in order to determine the crustal deformation of Thessaly region. These velocities derive from continuous GPS measurements, using a 7-year (2008-2014) daily GPS data processing; this time period is period is considered capable of providing reliable data for the strain analysis. The GPS data processing was carried out using GAMIT/GLOBK software (Herring et al., 2015) while the methodology described by Dong et al. (1998) was implemented. At first, the daily 30 sec GPS data were processed, using all updated models and standards following the IERS and IGS guidelines (http://acc.igs.org/reprocess.html). Secondly, the daily analysis, which contains station position estimations and variance-covariance information, were constrained to 24 IGS fiducial stations, estimating station coordinates and velocities calculated by a Kalman filtering sequential approach. The "raw" time series contribute to the recognition of possible outliers or discontinuities, occurring in site coordinates, which derive from various sources and have impact on long time series. Velocities are referred to the European Terrestrial Reference Frame 2000 (ETRF2000), considering the stable Eurasian Plate. Moreover, results were validated by the corresponding ones of other related studies. In particular, our velocity model was evaluated according to one of the most recent studies, including the largest global velocity solution in our days; the Global Strain Rate Model (GSRM v.2.1; Kreemer et al., 2014), where (horizontal) vectors differences do not exceed $2.5 \mathrm{~mm}$. GSRM is a synthetic model, aiming to the plate motions and strain rates determination in the boundary zones area, while it mainly includes bibliographically-based velocity values. In addition, velocity vectors are in accordance with study results (Müller et. al, 2013), based on continuous and campaign-type sites. In this case, the velocity values calculation was based on a model, which includes a linear trend, extended by additional annual and semi-annual sinusoidal terms.

In order to estimate the crustal deformation, the triangulation methodology was performed, which is based on the combination of geodetic data (velocity components and their uncertainties) of three different GPS stations. In particular, the three stations form a well-defined, equilateral triangle (the shortest distance between stations was considered), while for its centre (triangle centroid) a series of parameters is calculated, based on the corresponding mathematical equations, derived from the axes combination of the inner circle (i.e. the undeformed triangle situation) and the ellipse (i.e. the deformed triangle situation) (Lazos et al., 2021). In this context, 193 triangles were constructed throughout the study area, and for each one, the Maximum Horizontal Extension (MAHE), the Total Velocity (TV), the Maximum Shear Strain (MSS) and the Area Strain (AS) were estimated (http://www.unavco.org).

\subsection{MAXIMUM HORIZONTAL EXTENSION (MAHE)}

The MAHE parameter expresses the intensity of extensional tectonics in a region (when values are positive). In broader Thessaly the values range between -35 and 376 nano-strain, with extensional regime being the dominant one (Figs. 2a, b). The MAHE vectors show quite persistent, $c a$. N-S directions in southern Thessalian Basin (from Pagasitikos Gulf and westwards), where the highest values ( $>200$ nano-strain) also occur. Towards the westmost part though, a significant change of direction is observed, reaching $90^{\circ}$. At the very northern part of Thessaly, MAHE direction shows gradual change from NW to the west, N-S to the centre, and NE-SW to the east. Besides the southern margin of the Thessalian Basin, significant values ( $>150$ nanostrain) are observed near Mouzaki and the Larissa Fault, within the Larissa plain. Of particular interest are the negative, absolute low, values of MAHE just south of the 2021 epicentral area. In general, the 

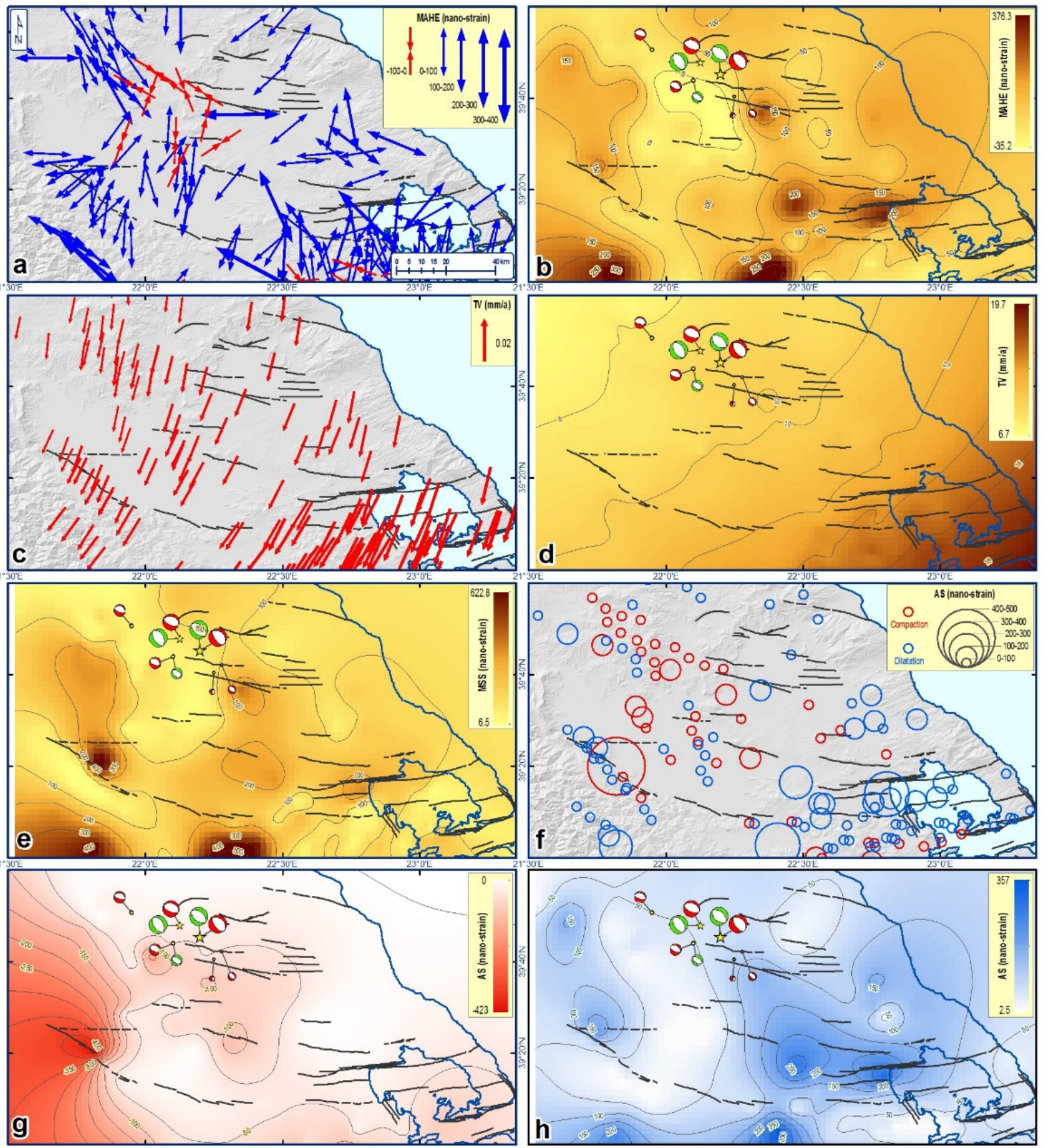

Fig. 2 (a, b) Maximum Horizontal Extension (MAHE) on barycentres as vectors (a) and interpolated (b). (c,d) Total Velocity (TV) on barycentres as vectors (c) and interpolated (d). (e) Maximum Shear Strain (MSS) interpolated. (f,g,h) Area Strain (AS) on barycentres as circles (f) and dilatation and compaction interpolated ( $\mathrm{g}$ and $\mathrm{h}$, respectively). The used interpolation method is Kriging. The major neotectonic/active faults and the moment tensor solutions (IG-NOA and GFZ) of the 2021 seismic sequence (Fig. 1b) are also shown. Toponyms are shown in Fig. 1b.

MAHE results show a gradual tectonic activity increase at the central and eastern part of Thessaly.

\subsection{TOTAL VELOCITY (TV)}

The TV parameter shows the motion of an area, strongly related to its geotectonic and geodynamic evolution. The values in our study area range between 6.7 and $25.3 \mathrm{~mm} / \mathrm{yr}$, with a SE direction of increasing values (Figs. 2c, d). The vectors direction reveals a smooth gradual change from $\mathrm{S}$ to $\mathrm{SW}$ as we move from north to south and southeast. In combination with the SE-ward increasing values, a SW motion with a clockwise rotation is assumed, confirming the results of Chousianitis et al. (2013).

\subsection{MAXIMUM SHEAR STRAINS (MSS)}

The MSS parameter is directly related to the faults or fault zones activity (mainly associated with 
extensional tectonics), indicating the shearing, occurring in a specific area. The MSS values of the Thessaly area range between 3 and 725 nano-strain. The MSS values analysis (Fig. 2e) shows that the highest values ( $>400$ nano-strain) are near Mouzaki (western part of the Thessalian Basin), and south of the Thessalian Basin (Pagasitikos Gulf). Intermediate values (near 200-400 nano-strain are observed along a N-S axis at the central part of the basin and all along the western basinal margin, from Mouzaki and northwards. The 2021 epicentral area is located within an area of low MSS values ( $<100$ nano-strain).

\subsection{AREA STRAIN (AS)}

The AS parameter represents the type of strain, dilatation or compaction, which can be related to the active tectonic structures of a study area. The former (dilatation) is directly associated with extensional tectonics and therefore with normal faulting, while the latter (compaction) is directly associated with compressional tectonics and therefore with reverse faulting. The coexistence of dilatation and compaction indicates strike-slip faulting. The AS values within the Thessaly area range between -423 and 357 nano- strain, indicating both dilatation and compaction (Figs. 2f, g, h). Compaction is mostly concentrated in western Thessaly $(|\mathrm{AS}|>100$ nanostrain) with some low absolute values (ca $50<|\mathrm{AS}|<$ 150 nano-strain) in the central part of the basin. Dilatation is more disperse with high values (AS $>200$ nano-strain) observed in SE Thessaly and the maximum south of the Thessalian Basin. Low, but noticeable values of dilatation (100-200 nano-strain) are observed near Mouzaki and the very NW part of the Thessalian Basin. In Mouzaki area, compaction is also intense (its maximum value occurs there) implying the presence of shear as well. In the epicentral area of the 2021 seismic sequence, both compaction and dilatation show small (absolute) values ( $\sim 50$ nano-strain).

\section{CONCLUSIONS - DISCUSSION}

\subsection{CRUSTAL DEFORMATION INTERPRETATION}

The Thessaly region is generally considered as a region of moderately active tectonics. The crustal deformation analysis suggests the dominance of active normal faulting; nevertheless, in the western part of the Thessalian Basin compressional faulting with shear may occur as well, due to the following reasons: i) high compaction with lower, but noteworthy dilatation coexistence (AS parameter), and ii) quite high MSS values. Indeed, near Mouzaki (western Thessalian Basin), MSS values exceed 400 nanostrain (Fig. 2e), whereas the AS-derived compaction of $c a$. 420 naneo-strain and dilatation of $c a .150$ nanostrain occur simultaneously (Figs. 2g, h), suggesting oblique-reverse faulting with significant shear component. This deformational regime implies the existence of transpressional strike-slip faulting. These tectonic structures are likely to be associated with the Apulian-Aegean collision in western Greece, resulted in the activation or potential activation of strike-slip structures, expanding throughout Greek mainland. North of Mouzaki, where compaction decreases closer to the dilatation values, shear becomes the dominant fault kinematics. Southwest of Mouzaki, both MSS and AS components decrease rapidly passing into a more dilatational regime towards the south Thessalian Basin. This transition is also supported by the gradual change of the MAHE vectors direction from E-W to the north to N-S to the south. Apart from western Thessaly, the rest region is characterized by the dominance of dilatation with significant MSS values indicating normal faulting activity; according to the MAHE vectors direction, the faults (or fault zones) strike varies between E-W (Pagasitikos Gulf area) and NW-SE (NNE part of Thessaly). The TV results imply that Thessaly is more and more involved in the southwestward Aegean (micro-)plate motion as we move from NW to S and SE, or else closer to the Hellenic Arc, showing common deformation characteristics (tectonic structures, kinematics, etc.) with the corresponding Aegean ones. These results are generally equivalent with previously published works (Perouse et al., 2012; Müller et al., 2013; Chousianitis et al., 2015), despite the fact that different techniques for the GPS processing are applied; however, the multiparametric approach of our paper adds detailed information in the strain issue, which reinforces geodynamic interpretations of the aforementioned previous works.

\subsection{THE 2021 EARTHQUAKE SEQUENCE IN THESSALY}

Although the crustal deformation analysis is not directly associated with the 2021 earthquake sequence (since the GPS measurements refer to an earlier 7-year period), some important conclusions can be drawn. Initially, the MAHE vectors direction are lacking in the narrow epicentral area since no barycentres occur from the applications of the triangulation methodology, preventing a direct observation and conclusion. Immediately to the south, a weak compressional field is exposed in a roughly NW-SE direction, whereas a little further to the north, a N-S-directing extensional regime is revealed. Perhaps, within this transitional zone, the NE-SW direction of extension occurs; however, this hypothesis is precarious, as it is exclusively based on the moment tensor solutions. In any case, the epicentral area demonstrates deformational complexity which cannot be explained with a simple uniform N-S-trending extension covering all Thessaly like it was believed (e.g. Caputo and Pavlides, 1991; 1993). Moreover, the low values of the MSS parameter indicate that the seismic area is subjected into a very low stress charge process, although the nearby Larissa fault shows higher values. The AS 
parameter reveals low dilatation and compaction values as well. In other words, the deformation process seems rather slow for the period 2008-2014.

Given that the GPS monitoring period is very short compared to the fault's seismic cycle, and that the state of the prior accumulated elastic deformation is unknown, then probably the so far accumulated strain, and consequently the stress load, was near to fault's rupture threshold. Therefore, it is concluded that the 2021 earthquake sequence is a short-term episode within a crustal area that undergoes long-term deformation, controlled by a wider stress regime; this regime is primarily characterized by a significant extensional field, as expressed by dip-slip normal faults, and secondarily by increased shear component values, mainly at the western part of Thessaly, represented by potential active strike-slip structures. Based on this analysis, similar earthquake phenomena cannot be excluded for the broader Thessaly area. Future research could include the estimation of the strain rate and its behaviour (stable, accelerating/decelerating, or irregular) during a similar time period and its association with the short-term slip-rate.

\section{ACKNOWLEDGEMENTS}

We acknowledge support of this study by the project "HELPOS - Hellenic Plate Observing System" (MIS 5002697) which is implemented under the Action "Reinforcement of the Research and Innovation Infrastructure", funded by the Operational Programme "Competitiveness, Entrepreneurship and Innovation" (NSRF 2014-2020) and co-financed by Greece and the European Union (European Regional Development Fund). We would also like to thank the NOANET (www.gein.noa.gr; Chousianitis et al., 2021), HxGN/SmartNet (www.metricanet.gr), HEPOS (www.hepos.gr) and HermesNet (users.auth.gr/cpik) providers for the GPS data, as well as the two anonymous reviewers for the constructive reviews that contributed to the manuscript improvement.

\section{REFERENCES}

Bitharis, S.: 2015, Process of GPS permanent stations data and estimation of velocity field in Greek area. Thesis. Aristotle University of Thessaloniki, (in Greek).

Bitharis, S., Fotiou, A., Pikridas, C. and Rossikopoulos, D.: 2016, A new velocity field of Greece based on seven years (2008-2014) continuously operating GPS station data (321-329). Springer, Cham. DOI: 10.1007/1345_2016_230

Caputo, R.: 1993, Morphotectonics and kinematics along the Tirnavos Fault, northern Larissa Plain, mainland Greece. Zeitsschrift für Geomorphol., 94, 167-185.

Caputo, R., Chatzipetros, A., Pavlides, S. and Sboras, S.: 2012, The Greek database of seismogenic sources (GreDaSS): State-of-the-art for northern Greece. Ann. Geophys., 55, 859-894. DOI: 10.4401/ag-5168
Caputo, R. and Pavlides, S.: 1993, Late Cainozoic geodynamic evolution of Thessaly and surroundings (central-northern Greece). Tectonophysics, 223, 339362. DOI: 10.1016/0040-1951(93)90144-9

Caputo, R. and Pavlides, S.: 1991, Neotectonics and structural evolution of Thessaly (Central Greece). Bull. Geol. Soc. Greece, 25, 119-133.

Chousianitis, K., Ganas, A. and Gianniou, M.: 2013, Kinematic interpretation of present-day crustal deformation in central Greece from continuous GPS measurements. J. Geodyn., 71, 1-13. DOI: 10.1016/j.jog.2013.06.004

Chousianitis, K., Ganas, A. and Evangelidis, C.P.: 2015, Strain and rotation rate patterns of mainland Greece from continuous GPS data and comparison between seismic and geodetic moment release. J. Geophys. Res., B Solid Earth, 120, 3909-3931. DOI: $10.1002 / 2014 J B 011762$

Chousianitis, K., Papanikolaou, X., Drakatos, G. and Tselentis, G.-A.: 2021, NOANET: A continuously operating GNSS network for Solid-Earth sciences in Greece. Seism. Res. Letters, 92, 3, 2050-2064. DOI: $10.1785 / 0220200340$

Dong, D., Herring, T.A. and King, R.W.: 1998, Estimating regional deformation from a combination of space and terrestrial geodetic data. J. Geod., 72, 200-214. DOI: $10.1007 / \mathrm{s} 001900050161$

Ekstrom, G. and England, P.: 1989, Seismic strain rates in regions of distributed continental deformation. J. Geophys. Res., 94, 10231-10257. DOI: 10.1029/jb094ib08p10231

Galanakis, D.: 1990, Neotectonic structure and stratigraphy of Neogene-Quaternary sediments of Almyros Basin Pagasitikos, Pelion, Orei-Trikeri strait and Maliac. PhD Thesis, Aristotle University of Thessaloniki, 258 pp., (in Greek).

Hatzfeld, D., Pedotti, G., Hatzidimitriou, P., Panagiotopoulos, D., Scordilis, M., Drakopoulos, I., Makropoulos, K., Delibasis, N., Latousakis, I., Baskoutas, J. and Frogneux, M.: 1989, The Hellenic subduction beneath the Peloponnesus: first results of a microearthquake study. Earth Planet. Sci. Lett., 93, 283291. DOI: $10.1016 / 0012-821 X(89) 90076-9$

Herring, T.A., King, R.W., Floyd, M.A. and McClusky, S.C.: 2015, GAMIT Reference Manual. GPS Analysis at MIT.

Hollenstein, C., Müller, M.D., Geiger, A. and Kahle, H.G.: 2008, Crustal motion and deformation in Greece from a decade of GPS measurements, 1993-2003. Tectonophysics, 449, 17-40.

DOI: $10.1016 /$ j.tecto. 2007.12 .006

http://acc.igs.org/reprocess.html

http://rcmt2.bo.ingv.it/

https://www.emsc-csem.org/Earthquake/emma.php

https://www.emsc-csem.org/\#2

https://www.globalcmt.org/CMTsearch.html

http://www.unavco.org

Jenny, S., Goes, S., Giardini, D. and Kahle, H.G.: 2004, Earthquake recurrence parameters from seismic and geodetic strain rates in the eastern Mediterranean. Geophys. J. Int., 157, 1331-1347.

DOI: 10.1111/j.1365-246X.2004.02261.x 
Kahle, H.-G., Cocard, M., Peter, Y., Geiger, A., Reilinger, R., Barka, A. and Veis, G.: 2000, GPS-derived strain rate field within the boundary zones of the Eurasian, African, and Arabian Plates. J. Geophys. Res., Solid Earth, 105, 23353-23370.

DOI: $10.1029 / 2000 J B 900238$

Kiratzi, A. and Louvari, E.: 2003, Focal mechanisms of shallow earthquakes in the Aegean Sea and the surrounding lands determined by waveform modelling: A new database. J. Geodyn., 36, 251-274. DOI: $10.1016 / \mathrm{S} 0264-3707(03) 00050-4$

Kourouklas, C., Console, R., Papadimitriou, E., Murru, M. and Karakostas, V.: 2021, Strong earthquakes recurrence times of the Southern Thessaly, Greece, Fault System: Insights from a physics-based simulator application. Front. Earth Sci., 9, 596854.

DOI: $10.3389 /$ feart.2021.596854

Kreemer, C., Blewitt G. and Klein, E.C.: 2014, A geodetic plate motion and global strain rate model. Geochem. Geophys. Geosyst., 15, 3849-3889.

DOI: $10.1002 / 2014 \mathrm{GC} 005407$

Lazos, I., Sboras, S., Pikridas, C., Pavlides, S. and Chatzipetros, A.: 2021, Geodetic analysis of the tectonic crustal deformation pattern in the North Aegean Sea, Greece. Mediterr. Geosci. Rev., 3, 79-94. DOI: 10.1007/s42990-021-00049-6

Müller, M.D., Geiger, A., Kahle, H.G., Veis, G., Billiris, H., Paradissis, D. and Felekis, S.: 2013, Velocity and deformation fields in the North Aegean domain, Greece, and implications for fault kinematics, derived from GPS data 1993-2009. Tectonophysics, 597-598, 34-49. DOI: $10.1016 /$ j.tecto.2012.08.003

Papadimitriou, E. and Karakostas, V.: 2003. Episodic occurrence of strong $(\mathrm{Mw} \geq 6.2)$ earthquakes in Thessalia area (central Greece). Earth Planet. Sci. Lett., 215, 395-409. DOI: $10.1016 / \mathrm{S} 0012-812 \mathrm{X}(03) 00456-4$

Papazachos, B. and Papazachou K.: 2003, Earthquakes of Greece. Ziti editions, Thessaloniki.

Papazachos, B.C., Panagiotopoulos, D.G., Tsapanos, T.M., Mountrakis, D.M. and Dimopoulos, G.C.: 1983, A study of the 1980 summer seismic sequence in the Magnesia region of Central Greece. Geophys. J. Int., $75,155-168$.

DOI: 10.1111/j.1365-246X.1983.tb01918.x

Perissoratis, C., Angelopoulos, I. and Mitropoulos, D.: 1991, Surficial Sediment Map of the Aegean Sea Floor, "Pagasitikos" Sheet, scale 1:200 000, Ed. IGME, Athens.

Perouse, E., Chamot-Rooke, N., Rabaute, A., Briole, P., Jouanne, F., Georgiev, I. and Dimitrov, D.: 2012, Bridging onshore and offshore present-day kinematics of central and eastern Mediterranean: Implications for crustal dynamics and mantle flow. Geochem. Geophys. Geosyst., 13, Q09013, DOI: $10.1029 / 2012 \mathrm{GC} 004289$

Sboras, S.: 2011, The Greek Database of Seismogenic Sources: seismotectonic implications for North Greece. University of Ferrara.

Taymaz, T., Jackson, J. and McKenzie, D.: 1991, Active tectonics of the north and central Aegean Sea. Geophys. J. Int., 106, 433-490.

DOI: $10.1111 / j .1365-246 X .1991 . t b 03906 . x$ 